\title{
"Winning Is Everything" as the Basis of Academic Misconduct Among Indonesian Students
}

\author{
Yeremias Jenaa, Kasdin Sihotanga
}

\begin{abstract}
Unethical behavior among university students such as cheating and plagiarism has weakened the character of honesty in education. This fact has challenged those who perceived education as a holistic process of internalizing values and norms that lead to the formation of students' moral principles and moral behaviour. Educators have played the role of ensuring the students to internalize and realized moral values and norms. A study of 360 students of the second semester who enrolled at the course of "ethical and personal development" at Atma Jaya Catholic University in Indonesia showed that unethical behavior such as cheating and plagiarism were rarely done. However, a deep look at the reason the students did academic dishonesty has prompted the permissiveness of student's moral life. This study proves that academic integrity among university students is worrisome, and it is worsened by the fact that they were enrolled in the course of "ethical and personal development". Seriously taking into consideration the strong desire of students to change the culture of academic misconduct, the authors argue that an educational model which is not oriented excessively to cognitive performance is needed. The authors argue that this position has to be practiced in line with the involvement of "clean" students who are involved as role models in influencing the formation of student awareness and ethical behavior.
\end{abstract}

Keywords

Cheating, plagiarizing, performance-oriented, goal-oriented, academic misconduct

Being the center for character education in Atma Jaya Catholic University in Indonesia, Personal Development Unit (PDU) is taking the responsibility of managing and developing the courses for the development of good character of the students. Various courses have been developed to realize this aim. Yet, for decades, teaching courses being offered have just fallen into the traditional education model with excessive emphasis on content-based (Biggs 2007). Although PDU has set the excellent values such as academic honesty, responsibility, tolerance, as its trademark, it is still not apparent what instruments will be used to cultivate them.
As the PDU still has to formulate and design a suitable approach for the cultivation of values, some major immoral behaviours continue to threaten student's academic activities. Two immoral behaviours that are now endangered students' moral and personal development are cheating and plagiarism.

aAtma Jaya Catholic University of Indonesia, Jakarta, Indonesia

\section{Correspondent Author:}

Yeremias Jena, Ethics/Philosophy Unit, Atma Jaya School of Medicine, Jalan Pluit Raya 2, Jakarta 14440, Indonesia E-mail: yeremias.jena@gmail.com 
The responsibility of PDU then becomes increasingly severe. On the one hand, it should immediately formulate the approach in cultivating the excellent values-whether through offering some courses on ethics or through an integrative approaches (Sihotang et al. 2011). On the other hand, immoral behaviours of the students should be addressed immediately, and it cannot rely on the courses being offered due to its traditional method of teaching. Moreover, the excellent values to be cultivated had not been designed systematically.

An initial research on academic misconduct is needed as a first step to detect the severity of immoral behaviours of the students. This early detection aimed at finding out whether immoral behaviours such as cheating and plagiarism occured in student's academic activities. How severe is it? Are there any sufficient motivation and courage from the students to abandon such behaviour?

\section{METHOD}

This research was conducted in PDU, part of the character development unit in Atma Jaya Catholic University in Indonesia. The courses that are developed in PDU covers all areas of the humanities and civic education, such as critical thinking, multiculturalism, religion, and civic education.

Critical thinking is one of the subjects with more than 10 parallel classes and must be taken by all students. Taking into account the fact that the students studying critical thinking were coming from different faculties, it can be said that they represented the diversity of the respondents. This is the reason of choosing the students who took the course of critical thinking as respondents. There were 12 parallel classes taking the course in even semester of 2012/2013 with 720 as potential respondents. Systematic sampling used to determine the number of samples (Noor 2011) resulted in 30 students as respondents in each class. They were asked to fill up five questions on June 18-28, 2013. The five questions covers: (1) the identity of respondents (anonymously), age, gender, and faculty origin; (2) the frequency of academic misconduct such as cheating and plagiarism; (3) the reasons for cheating and the courage to stop the act; (4) the reasons for doing plagiarism and the courage to stop the act; and (5) strategies being applied to hinder the students from such a behaviour (those who never did academic misconduct).

The data then analyzed to see the frequency the students performed unethical actions, motivations behind such behaviours, and to disclose moral courage the students have to get rid of it. The tabulated data then interpreted to highlight how they related to each other from certain theoretical perspectives.

\section{RESULT AND DISCUSSION}

This research showed that the frequency of "most often" and "often" practice of cheating was $27.22 \%$ (98 respondents) compare with $8.89 \%$ (32 students) who had "never cheat". The same condition was the picture of the students who did plagiarism. This research demonstrated that Indonesian students rarely did plagiarism ( $55.83 \%$ of 201 respondents). Very low percentage of the students $(21.94 \%)$ who plagiarized "most oftenly" or "frequently", whereas the rest $(22.22 \%)$ are the student who never done any kind of plagiarism.

Nonetheless, considering to the idealism of the university to create higly academic integrity characterized by the absence of disgraceful behaviors such as cheating or plagiarizing, this condition was still far from ideal. Claiming that Indonesian students "rarely" performed academic misconduct did not mean to deny the practice of academic misconduct among them if it was taking into account the fact that such academic misconduct had been performed atleast one to five times. Some previous studies in Indonesia showed that cheating has been a common thing that mostly occured in the context of doing homework, 
quizzes, and exams (Jahja 2007). Some scholars added that cheating behavior has become part of the culture of school, children and college students in such a way that lead to the conclusion that academic misconduct was accepted as a common practice. This misconception made it difficult for PDU to cultivate the values of honesty and integrity during the process of education in an academic realm (Pujiatni and Lestari 2010; Jones 2011; E. Park, S. Park, and Jang 2013).

Academic misconduct might have negative influence on $8.89 \%$ who never cheated and of $22.22 \%$ who never plagiarized. This result emphasized the idea that students who are "clean" can be affected by unethical behaviour of their colleges (Nucci and Narváez 2008). Considering the fact that $22.78 \%$ of "clean" students were never tempted to commit academic misconduct, the responsibility must be on the shoulders of each educational community to prevent them from the same mistake. It is interesting to note that among the students who never conduct unethical behaviours, $7.50 \%$ of them understood it as a responsibility to oneself, $6.67 \%$ did it due to a desire to always being honest, $3.89 \%$ based their act on the fear of $\sin , 1.67 \%$ refered it as a command of conscience, $1.67 \%$ because of fear of being withdrawn from the class, while $1.11 \%$ refered it as a commitment to religious faith. Again, these facts underlined the responsibility of any educational community to not only prevent the students falling into the same misconducts, but also to involve them as key roles in cultivating moral and ethical values.

\section{Reason for Unethical Behaviours}

Most unethical behaviours were carried out in different contexts with different motives (Kwong et al. 2010; Comas-Forgas and Sureda-Negre 2010; Wheeler 2009). The students cheated mostly during the time of doing the quiz $(61.39 \%)$, followed by midterm exams and final exams (23.06\%). If the reason for cheating was student's difficulty in comprehending the subjects $(20.56 \%)$, people may tend to excuse such a conduct by considering the fact that quizzes were always held only a few days after the subjects were being taught. However, there were still other factors that drove students to cheat. It was about $11.39 \%$ of the students were "less confident" of themselves, $8.89 \%$ were "fear of providing the wrong answer", and $8.33 \%$ "forgot the steps of solving the problem", and $7.78 \%$ of students were "fear of getting a bad score". Moreover, the lecturers also expected perfect answers from the students (2.22\%).

No students admitted that they had done unethical behaviours in purpose. It was about $6.11 \%$ of students said that they cheated by chance or "forced by the situation". However, this motive should be carefully analyzed. It was about $18.33 \%$ of the students did the quizzes without preparation and $11.39 \%$ did it in the condition of lack of self-confidence. Moreover, the data also showed that the real motives for cheating were laziness and desire to achieve high and good grades. This result is in line with researches by scholars (Jahja 2007; Hosny and Fatima 2014), who stated that the students wanted to get good grades without studying hard, or by Simkin and McLeod who indicated that the desire to be successful students driven by the principle of "winning is everything" was oftenly not supported by a willingness to study harder (Simkin and McLeod 2010).

Why the principle of "winning is everything" was able to entrap students' moral integrity? Why was the misperception that cheating is morally wrong not able to prevent them from academic misconduct? As shown in this study, the pressure to achieve high grades without efforts to learn has become one of the strong reasons for cheating. However, a deeper motivation can actually be detected by referring it to other similar studies. Anderman and Murdock argued that the act of cheating is strongly influenced by personal factors, be it the atmosphere of the lecture hall or the wider external orientation (Anderman, Griesinger, and Westerfield 1998). At the personal 
level, students might have motivational perspective called goal approach or performance approach. Goal-oriented approach gives importance more on the broader goal of learning process rather than merely getting good grades. This approach is belief to be effective in minimalizing academic misconduct such as cheating. On the other hand, performance-oriented approach favors not only the end results of competency tests provided by quizzes and other forms of cognitive tests, but also tended to judge student's performance as "good" or "poor". The nature of this approach has triggered the students to be afraid of getting poor performance that might lead to having low self-confidence. Again, this echoed the conclusion of some researches as stated before (Kwong et al. 2010; Comas-Forgas and Sureda-Negre 2010; Wheeler 2009).

Similar motivation (the desire to get high grades or fear of getting low grades) was also seen in the practice of plagiarism among Indonesian students. Most students plagiarized in paper writing (27.43\%) for several reasons as follow: (1) paper assignment itself is difficulty to carry out (8.33\%); (2) inability to explore one's ideas (11.93\%); (3) the desire to finish the assignment quickly (16 respondents); or (4) the absence of writing skills (2.78\%). However, the data indicated that the desire to achieve high grades was not supported by hard effort in writing a paper or completing an assignment. Students showed the difficulty in breaking away from plagiarism due to the fact that they failed to liberate themselves from the laziness of reading and thinking $(22.22 \%)$.

\section{From Performance-Oriented to Goal-Oriented}

The description above implied that no student ever cheating or plagiarizing as a learning strategy. In the context of value education, it should be assumed as well that all students want to be moral person. When talk about academic misconduct (cheating and plagiarizing), there are two aspects that should be considered seriously. First, how to encourage the students to return to the state of being "good guys". Second, how to save the rest of the students who have not been contaminated with such behavior.

Regarding the first question, this research showed positive signs toward behavioral change. The data indicated that $63.61 \%$ of students have strong desire to stop cheating (229 respondents) as well as $46.39 \%$ of them expressed strong will to stop plagiarizing (167 respondents). However, good intentions alone are not sufficient for moral change when one consider the fact that $53.61 \%$ of students find it difficult to leave that bad habit as for $51.94 \%$ to quit from plagiarism. This fact showed that on the one hand, there exists an optimism that students have the ability to quit from those misconducts, while on the other hand, students still found it difficult to break away from them.

The reasons for cheating such as fearing the wrong answer and getting low grades have actually represented what is called performance-oriented model of education. As an approach, this model of education gave importance more at highest level of educational as stated in the curriculum without taking into account specific needs of students in a given context. The same standard must be said about paper writing when students were required to produce the papers as perfectly as expected by lecturers. The last gave rise the need to read the models that can lead to copy-pasting and plagiarism. This burden has caused the students to lose self-confidence in answering the quizzes as well as writing papers. Facing this situation, what is needed is to change educational approach from performance-oriented to broader or goal-oriented. Following the line of thoughts of Nel Noddings, any education must be organized in a community of education that is able to reduce unhealthy competition, which relies solely on the success of one show performance (Nucci and Narváez 2008).

From the perspective of moral and character education, the "clean" student should be involved as model. Instead of being purely scientific, higher education is conducted within a culture embedded 
with certain values (Boulton 2009). If the academic integrity such as honesty, fairness, kindness, tolerance, and the like were considered to be cultural values that affect the way students learn and cultivate sciences, then focus of education must be given to the efforts to involve actively the "clean" students as agent of change. Caring perspective or modelling in education as named by Nel Noddings or moral exemplars in the thoughts of Lawrence Kohlberg (Nucci and Narváez 2008) can be applied as model in educating values and character. Whatever the terminology will be, the main idea that has to be underlined is as clear as stated in the following quotation: “... observing those who practiced moral principles was a more direct method of teaching than any theory could hope to attain" (Nucci and Narváez 2008). In other word, any educational climate that relied heavily on unhealthy competition should be reduced when one take values and character education seriously.

This kind of paradigm shift that from performance-oriented to goal-oriented is self-evident. It requires all stake holders in the community of education to create a climate of education minus unhealthy competition and the urgency to involve clean students as role models. However, followed the proposal of Nel Noddings, in order to be effective role models, the clean students have to be proclaimed publicly, their moral achievements have to be appreciated, their way of life must be discussed openly, and continue to promote the group of students who are willing to act morally. Putting it in the context of this research, academic community is facing a single alternative in its mission to assist the students avoiding academic misconducts: to base character education on goal-oriented rather than performance-oriented.

\section{CONCLUSIONS}

Four conclusions can be drawn as follows. First, the desire to get high scores has been the reason for cheating and plagiarizing. Putting aside this positive desire, the way to attain the goal is ethically wrong. Based on this fact, this paper has argued that there must be a paradigm shift in education, especially in doing character education if one is to take character education seriously. Prompted this to character education in Indonesia, it is time to end the education that meassure its achievement solely on performace and unhealthy competition.

Second, students' moral courage and commitment to change should be encouraged. Considering the fact that a large number of students cheating and plagiarizing because of non-academic traits such as laziness in learning and lack of self-confidence, character education should also encourage the formation of self-confidence as well as motivating them to study hard.

Third, character education at university level needs to empowering "clean" students as role model. Moral education and formation of behavior often becomes more effective if the students observe and imitate good model.

Fourth, further research is needed to see whether or not the burden of learning (too many quizzes, assignments, and papers, or high demand of the lecturers to get qualified papers from the students) is leading to academic misconduct. Such research is also expected to explain the assumption that demanding and burdensome education will create unhealthy competition that lead to academic misconduct.

\section{Acknowledgements}

The authors profited from discussion of these issues with the lecturers of character and values development in Personal Development Unit (PDU) at Atma Jaya Catholic University of Indonesia.

\section{References}

Anderman, E. M., T. Griesinger, and G. Westerfield. 1998. "Motivation and Cheating During Early Adolescence." 
Journal of Educational Psychology 90(1):84-93.

Biggs, J. 2007. "Teaching for Quality Learning at University." Higher Education 9:165-203. Retrieved (http://teaching. polyu.edu.hk/datafiles/R131.pdf).

Boulton, G. 2009. "What Are Universities For?" University World News. Retrieved (http://www.universityworldnews. com/article.php?story=20090326200944986).

Comas-Forgas, R. and J. Sureda-Negre. 2010. "Academic Plagiarism: Explanatory Factors From Students' Perspective." Journal of Academic Ethics 8(3):217-232.

Hosny, M. and S. Fatima. 2014. "Attitude of Students Towards Cheating and Plagiarism: University Case Study." Journal of Applied Sciences 14(8):748-757. Retrieved (http:// docsdrive.com/pdfs/ansinet/jas/0000/52640-52640.pdf).

Jahja, A. S. 2007. Integritas Akademik dalam Membangun SDM Profesional di Perguruan Tinggi: Kasus Academic Dishonesty STIE Perbanas (Academic Integrity in the Formation of Professional Human Capital in University: The Case of Academic Dishonesty at Perbanas Economic School). Jakarta. Retrieved (https://repository. perbanasinstitute.ac.id/xmlui/bitstream/handle/123456789/9 28/Jurnal Ilmu Pendidikan 2007.pdf? sequence=1).

Jones, D. L. R. 2011. "Academic Dishonesty: Are More Students Cheating?" Business Communication Quarterly 74(2):141-150.

Kwong, T., H.-M. Ng, K.-P. Mark, and E. Wong. 2010. "Students' and Faculty's Perception of Academic Integrity in Hong Kong." Campus-Wide Information Systems 27(5):341-355.

Noor, J. 2011. Metodologi Penelitian (Research Method). Jakarta: Kencana Prenada Media Group. Retrieved (http://library.fis.uny.ac.id/index.php?p=show_detail\&id=1 516).

Nucci, L. and D. Narváez. 2008. Handbook of Moral and Character Education. New York: Routledge. Retrieved
(http://books.google.co.id/books/about/Handbook_of_Mora 1_and_Character_Educatio.html?id=bZ8gzPywS7IC\&redir_ $\mathrm{esc}=\mathrm{y})$.

Park, E. J., S. Park, and I. S. Jang. 2013. "Academic Cheating Among Nursing Students." Nurse Education Today 33(4):346-352.

Pujiatni, K. and S. Lestari. 2010. "Studi Kualitatif Pengalaman Menyontek pada Mahasiswa" (Qualitative Study on Student's Cheating). Jurnal Penelitian Humaniora 11(2):103-110. Retrieved (http://publikasiilmiah.ums.ac. id:8080/xmlui/bitstream/handle/123456789/658/1.KRIS.pdf ?sequence=1).

Sihotang, K., P. P. Salamin, Y. Jena, R. A. Benedictus, and M. S. Halim. 2011. Best Practices of Character Building: Kejujuran sebagai Budaya Akademik (Honesty as an Academic Culture). Edited by Sutopo. Jakarta: Universitas Atma Jaya. Retrieved (https://lib.atmajaya.ac.id/ default.aspx?tabID=61\&src=k\&id=180135).

Simkin, M. G. and A. McLeod. 2010. "Why Do College Students Cheat?" Journal of Business Ethics 94(3):441-453.

Wheeler, G. 2009. "Plagiarism in the Japanese Universities: Truly a Cultural Matter?" Journal of Second Language Writing 18(1):17-29.

\section{Bios}

Yeremias Jena, MA of Philosophy and MA of Science in Bioethics, Department of Ethics, Atma Jaya School of Medicine, Atma Jaya Catholic University of Indonesia, Jakarta; research fields: bioethics and applied philosophy.

Kasdin Sihotang, MA of Philosophy, Atma Jaya School of Economic and Bussiness, Atma Jaya Catholic University of Indonesia, Jakarta; research fields: character education, philosophy of man, and bussiness ethics. 